\title{
Laryngeal Cancer Pathologic TNM Finding v8
}

National Cancer Institute

\section{Source}

National Cancer Institute. Laryngeal Cancer Pathologic TNM Finding v8. NCI Thesaurus. Code C133098.

A pathologic finding about one or more characteristics of laryngeal cancer, following the rules of the TNM AJCC V8 classification system. 